\title{
Forensic Analysis of Firearm Injuries in Fayoum Governorate in the Period from 2011 to 2016
}

\author{
Enas M. Morsi Mohammed and Amro A. Saleh ${ }^{1}$
}

${ }^{1}$ Department of Forensic Medicine and Clinical Toxicology, Faculty of Medicine, Fayoum University, Fayoum, Egypt.

\begin{abstract}
Background: Firearm injuries represent a leading cause of morbidity and mortality. The incidence varies over time and according to geographic region.

Aim of the work: The aim of our study was to illustrate the epidemiology of firearmrelated injuries and point to pattern of firearm violence in Fayoum Governorate-Egypt.

Methodology: comparative observational study on firearm injuries reported by Forensic Medical Authority in Fayoum Governorate from the period of January 2011 to December 2016. Firearm injuries related to demonstrations or political events were excluded.

Results: male gender constituted about $89 \%$ while female gender represented $10 \%$ of the study population. $40 \%$ were urban and $60 \%$ were rural. About one percent of study group showed fatal injuries. Quarrels were on the top of the list of the known causes of firearm injuries (13\%). Conclusion: We concluded that, the incidence of fire arm injuries was high in 2011 and gradually decreased through 2012 and 2013 then an increase was noticed in 2014 followed by a decrease to the least percentage recorded through the study period in 2016.
\end{abstract}

Key words Fayoum; Firearm; Revolution.

\section{Introduction}

$\mathrm{F}$ irearm injuries are one of the main causes of mortality and morbidity throughout the world; their destructive effects cause physical and psychological problems for persons and communities (Saidi et al., 2002; Mohammed et al., 2005).

Although the consequences of firearm injuries either fatal or non-fatal are often considered as acute trauma episodes, survivors usually need a considerable amount of hospital care. Moreover, medical, social and legal complications are common with high economic burden (Sachan et al., 2013).

Firearm injuries are commonly because of either interpersonal conflict, suicidal behavior or accidental release of weapons (Lustenberger et al., 2011).

There are critical varieties among districts and nations, as the rate of firearm-related deaths in low to middle-income nations was commonly more than twice that in high-income nations (Khetran et al., 2012).

After the revolution of 2011, an expansion in frequency of violence was noted in Egypt. Detailed armed robberies expanded from 233 out of 2010 to 2,807 amid 2012, while home attacks climbed from 7,368 of every 2010 to 11,699 out of 2012. The occurrence of firearm injuries has been connected to impairment of law and low income (Sameh et al., 2016).

No epidemiological studies were published till present to evaluate the incidence of firearm injuries in Fayoum governorate after the Egyptian revolution of
2011; hence, this study aimed at analysis of firearm injuries in Fayoum governorate after the revolution of 2011.

\section{Subjects and methods}

This study is a comparative observational study on firearm injuries reported by Forensic Medical Authority in Fayoum Governorate from the period of January 2011 to December 2016. Firearm injuries related to demonstrations or political events were excluded.

Collected data were categorized, for statistical purposes, regarding gender of the victim, residence, type of the weapon, cause of the crime, site of injuries, fatality of crime and distance $\}$. Obtained data on cases from 2011 to 2013 were analyzed and compared with data obtained after the revolution from 2013 to 2016.

Data were collected and coded to facilitate their manipulation. Analysis was performed using Statistical Package of Social Science (SPSS) software version 18 in windows 7.

\section{Results}

In the current study, male gender constituted about $89 \%$ while female gender represented $10 \%$ of the study population. According to residence, inhabitant urban area $40 \%$ compared to $60 \%$ for rural sites (table 1 ).

Incidence of firearm injuries was high in 2011 (23.7\%) and gradually decreased to (13.9\%) in 2013. An increase was noticed in 2014 (22.8\%) and this was followed by a decrease to the least percentage recorded 
through the study period in 2016 (4.7\%) as shown in table (2) and figure (1).

As regard fatality of cases, about one percent of study group showed fatal injuries. Quarrels were on the top of the list of the known causes of firearm injuries (13\%) while the least one was related to accidental in weddings (2\%). Limbs appeared to be the most injured site (57\%) (Table 3).

In the present study, no statistically significant difference was found between different years of the study as regards sex, residence, site of injury, fatality rate, cause of crime and type of used weapon (table 4).
By analysis of study variables according to type of weapon, a statistically significant difference was noted regarding sex, residence and the site of injury, where the majority of firearm injuries with both types of weapon occurred among males from rural areas and the most common site of injury was the limbs (table 5).On the other hand, no statistically significant difference was found as regards fatality rate and cause of crime in relation to the type of weapon (table 5).

This study showed that there is no statistically significant difference in fatality of cases regarding their residence (table 6).

Table (1): Number and percentage of cases regarding their demographic data (2011-2016)

\begin{tabular}{|c|c|c|}
\hline \multirow{2}{*}{ Variables } & \multicolumn{2}{|c|}{ Frequency } \\
\cline { 2 - 3 } & No. & \% \\
\hline \multicolumn{3}{|c|}{ Sex } \\
\hline Males & $\mathbf{4 1 9}$ & $89 \%$ \\
\hline Females & 50 & $11 \%$ \\
\hline \multicolumn{3}{|c|}{ Residence } \\
\hline Urban & 187 & $40 \%$ \\
\hline Rural & $\mathbf{2 8 2}$ & $60 \%$ \\
\hline Total & 469 & $100 \%$ \\
\hline
\end{tabular}

Table (2): Statistical distribution of fire arm injuries from 2011 to 2016

\begin{tabular}{|c|c|c|}
\hline \multirow{2}{*}{ Year of fire arm injury } & \multicolumn{2}{|c|}{ Frequency } \\
\cline { 2 - 3 } & No. & \% \\
\hline 2011 & 111 & $23.7 \%$ \\
\hline 2012 & 74 & $15.8 \%$ \\
\hline 2013 & 65 & $13.9 \%$ \\
\hline 2014 & 107 & $22.8 \%$ \\
\hline 2015 & 90 & $19.2 \%$ \\
\hline 2016 & 22 & $4.7 \%$ \\
\hline Total & 469 & $100 \%$ \\
\hline
\end{tabular}

Table (3): Statistical distribution of firearm injuries regarding different variables from 2011 to 2016.

\begin{tabular}{|c|c|c|}
\hline \multirow{2}{*}{ Variables } & \multicolumn{2}{|c|}{ Frequency } \\
\hline & No. & $\%$ \\
\hline \multicolumn{3}{|c|}{ Fatality } \\
\hline Fatal & 3 & $1 \%$ \\
\hline Non-fatal & 466 & $99 \%$ \\
\hline \multicolumn{3}{|c|}{ Cause of crime $(n=81)$} \\
\hline Unreported & 388 & $83 \%$ \\
\hline Quarrel & 62 & $13 \%$ \\
\hline Wedding & 10 & $2 \%$ \\
\hline Robbery & 9 & $2 \%$ \\
\hline \multicolumn{3}{|c|}{ Site of injury $(n=466)$} \\
\hline Unreported & 3 & $1 \%$ \\
\hline Limbs & 265 & $57 \%$ \\
\hline Trunk & 63 & $13 \%$ \\
\hline Head \& neck & 53 & $11 \%$ \\
\hline More than one sites & 85 & $18 \%$ \\
\hline
\end{tabular}


Table (4): Chi-square statistical analysis of study variables from 2011 to 2016 .

\begin{tabular}{|c|c|c|c|c|c|c|c|}
\hline \multirow{2}{*}{ Variables } & \multicolumn{6}{|c|}{ Years follow up } & \multirow{2}{*}{ p-value } \\
\hline & 2011 & 2012 & 2013 & 2014 & 2015 & 2016 & \\
\hline \multicolumn{8}{|c|}{ Sex } \\
\hline Males & $100(90.1 \%)$ & $61(82.4 \%)$ & $58(89.2 \%)$ & $100(93.5 \%)$ & $79(87.8 \%)$ & $21(95.5 \%)$ & \multirow{2}{*}{0.2} \\
\hline Females & $11(9.9 \%)$ & $13(17.6 \%)$ & $7(10.8 \%)$ & $7(6.5 \%)$ & $11(12.2 \%)$ & $1(4.5 \%)$ & \\
\hline \multicolumn{8}{|c|}{ Residence } \\
\hline Urban & $51(45.9 \%)$ & $29(39.2 \%)$ & $27(41.5 \%)$ & $41(38.3 \%)$ & $31(34.4 \%)$ & $8(36.4 \%)$ & \multirow{2}{*}{0.7} \\
\hline Rural & $60(54.1 \%)$ & $45(60.8 \%)$ & $38(58.5 \%)$ & $66(61.7 \%)$ & $59(65.6 \%)$ & $14(63.6 \%)$ & \\
\hline \multicolumn{8}{|c|}{\begin{tabular}{|l} 
Type of weapon \\
\end{tabular}} \\
\hline $\begin{array}{c}\text { Rifled } \\
\text { weapon }\end{array}$ & $35(31.5 \%)$ & $37(50 \%)$ & $21(32.3 \%)$ & $42(39.3 \%)$ & $27(30 \%)$ & $8(36.4 \%)$ & \multirow[t]{2}{*}{0.09} \\
\hline Shot gun & 76(68.5\%) & $37(50 \%)$ & $44(67.7 \%)$ & $65(60.7 \%)$ & $63(70 \%)$ & $14(63.6 \%)$ & \\
\hline \multicolumn{8}{|c|}{ Fatality } \\
\hline Fatal & $0(0 \%)$ & $0(\%)$ & $0(0 \%)$ & $3(2.8 \%)$ & $0(0 \%)$ & $0(0 \%)$ & \multirow{2}{*}{0.07} \\
\hline Non-fatal & $111(100 \%)$ & $74(100 \%)$ & $65(100 \%)$ & $104(97.2 \%)$ & $90(100 \%)$ & $22(100 \%)$ & \\
\hline \multicolumn{8}{|c|}{ Cause of crime } \\
\hline Quarrel & $21(67.7 \%)$ & $12(66.7 \%)$ & $19(95 \%)$ & $2(50 \%)$ & $6(100 \%)$ & $2(100 \%)$ & \multirow{3}{*}{0.1} \\
\hline $\begin{array}{l}\text { Accidental } \\
\text { in wedding }\end{array}$ & $4(12.9 \%)$ & $3(16.7 \%)$ & $1(5 \%)$ & $2(50 \%)$ & $0(0 \%)$ & $0(0 \%)$ & \\
\hline Robbery & $6(19.4 \%)$ & $3(16.7 \%)$ & $0(0 \%)$ & $0(0 \%)$ & $0(0 \%)$ & $0(0 \%)$ & \\
\hline \multicolumn{8}{|c|}{ Site of injury } \\
\hline Limbs & $58(52.7 \%)$ & $42(57.5 \%)$ & $41(64.1 \%)$ & $63(58.9 \%)$ & $54(50 \%)$ & $16(72.7 \%)$ & \multirow{4}{*}{0.5} \\
\hline Trunk & $15(13.6 \%)$ & $11(15.1 \%)$ & $6(9.4 \%)$ & $10(9.3 \%)$ & $18(20 \%)$ & $3(13.6 \%)$ & \\
\hline $\begin{array}{c}\text { Head \& } \\
\text { neck }\end{array}$ & $18(16.4 \%)$ & $7(9.6 \%)$ & $7(10.9 \%)$ & $11(10.3 \%)$ & $9(10 \%)$ & $1(4.5 \%)$ & \\
\hline $\begin{array}{l}\text { More than } \\
\text { one site }\end{array}$ & $19(17.3 \%)$ & $13(17.8 \%)$ & $10(15.6 \%)$ & $23(21.5 \%)$ & $18(20 \%)$ & $2(9.1 \%)$ & \\
\hline
\end{tabular}

$* P<0.05:$ statistically significant $p>0.05=$ statistically non-significant

Table (5): Chi-square statistical analysis of study variables in different types of weapons from 2011 to 2016.

\begin{tabular}{|c|c|c|c|c|c|}
\hline \multirow{2}{*}{ Variables } & \multicolumn{2}{|c|}{ Rifled weapon } & \multicolumn{2}{|c|}{ Shot gun } & \multirow{2}{*}{ p-value } \\
\hline & No. & $\%$ & No. & $\%$ & \\
\hline \multicolumn{6}{|c|}{ Gender } \\
\hline Males & 160 & $94.1 \%$ & 259 & $86.6 \%$ & \multirow{2}{*}{$0.01 *$} \\
\hline Females & 10 & $5.9 \%$ & 40 & $13.4 \%$ & \\
\hline \multicolumn{6}{|c|}{ Residence } \\
\hline Urban & 53 & $31.2 \%$ & 134 & $44.8 \%$ & \multirow{2}{*}{$0.004 *$} \\
\hline Rural & 117 & $68.8 \%$ & 165 & $55.2 \%$ & \\
\hline \multicolumn{6}{|c|}{ Fatality } \\
\hline Fatal & 2 & $1.2 \%$ & 1 & $0.3 \%$ & \multirow{2}{*}{0.3} \\
\hline Non-fatal & 168 & $98.8 \%$ & 298 & $99.7 \%$ & \\
\hline \multicolumn{5}{|c|}{ Cause of crime } & \multirow{4}{*}{0.6} \\
\hline Quarrel & 17 & $70.8 \%$ & 45 & $78.9 \%$ & \\
\hline $\begin{array}{l}\text { Accidental in } \\
\text { wedding }\end{array}$ & 3 & $12.5 \%$ & 7 & $12.3 \%$ & \\
\hline Robbery & 4 & $16.7 \%$ & 5 & $8.8 \%$ & \\
\hline \multicolumn{6}{|c|}{ Site of injury } \\
\hline Limbs & 110 & $65.5 \%$ & 155 & $52 \%$ & \multirow{4}{*}{ 0.01* } \\
\hline Trunk & 21 & $12.5 \%$ & 42 & $14.1 \%$ & \\
\hline Head \& neck & 10 & $6 \%$ & 43 & $14.4 \%$ & \\
\hline More than one sites & 27 & $16.1 \%$ & 58 & $19.5 \%$ & \\
\hline
\end{tabular}

$* P<0.05$ : statistically significant, $S E$ : standard error 
Table (6): Chi-square statistical analysis of study variables regarding residence in different fatality group

\begin{tabular}{|c|c|c|c|c|c|}
\hline \multirow{2}{*}{ Variables } & \multicolumn{2}{|c|}{ Fatal } & \multicolumn{2}{c|}{ Non-fatal } & \multirow{2}{*}{ p-value } \\
\cline { 2 - 4 } & No. & $\mathbf{\%}$ & No. & $\mathbf{\%}$ & \multirow{2}{*}{0.6} \\
\hline Urban & 2 & $67 \%$ & 185 & $40 \%$ & \multirow{2}{*}{ Residence } \\
\hline Rural & $\mathbf{1}$ & $\mathbf{3 3 \%}$ & 281 & $60 \%$ & \\
\hline
\end{tabular}

$* P<0.05$ : statistically significant $p>0.05=$ statistically non-significant

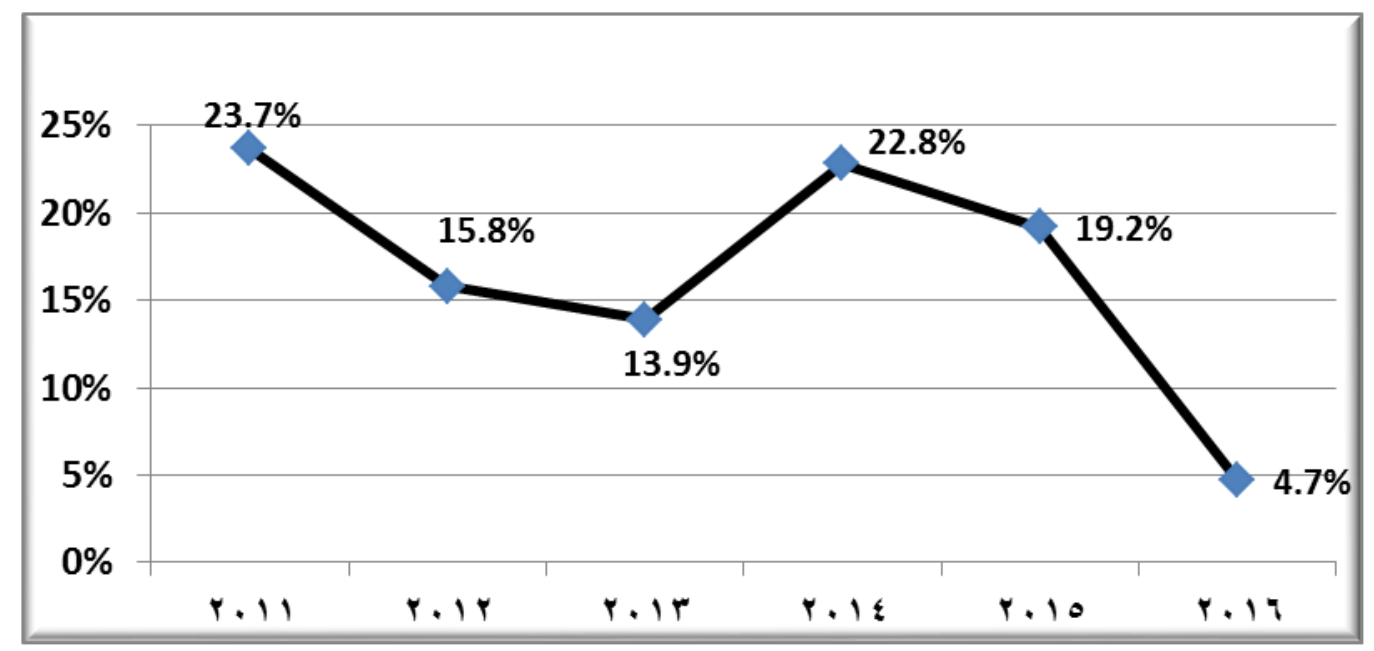

Fig (1): Distribution of firearm injuries recorded cases from 2011 to 2016

\section{Discussion}

The prevalent impacting factor in firearms injuries is weapon accessibility. In the United States of America (USA), the firearms rate is higher because of more prominent gun possessions, regardless of whether legally or illegally through weapon dealing and lesser guns limitation (Braga et al., 2012). Furthermore, keeping guns at home for protection is regular in the USA. Nonetheless, rather than utilizing guns for protection, accessibility of guns at home expanded danger of death (Shenassa et al., 2004).

Studies from the United States and other developed countries announced that firearms are utilized in over $60 \%$ all homicides, over $25 \%$ of all attacks, over $35 \%$ of all robberies and almost half of all suicides (McGuire et al., 2011). North Africa and Middle East showed 25.4\% unintentional deaths from firearms, 15.6\% suicide and 59.0\% homicide (Naghavi and Marczak, 2018).

Outfitted Violence Map pronounced that, the assessed civilian gun possession rates in North Africa extend from Africa's most reduced, Tunisia (0.1 guns per 100 individuals), to one of Africa's most noteworthy, Libya (15.5). The rest ranges from 3.5 in Egypt to 7.6 in Algeria (Evoy and Hideg, 2017).

In Egypt, about $68 \%$ of homicide cases are caused by firearm, $19 \%$ by sharp objects and $13 \%$ by other causes (Sameh et al., 2016). According to mortality statistics provided by WHO, the annual rate of all gun deaths per 100,000 population in Tunisia, 2013 is 0.05 and Morocco 2012 is 0.01 (WHO, 2016).

The current study is a retrospective analysis of firearm injuries examined by the Forensic Medical
Authority in Fayoum Governorate from the period of January 2011 to December 2016. Our results indicate that, the highest percentage of firearm injuries in Fayoum Governorate occurred in 2011 (after the revolution of January 2011) in relation to the other years of study period as the incidence gradually decreased in 2013. An increase was noticed in 2014, this was followed by a decrease to the least percentage recorded through the study period in 2016.

This was in accordance with Samy et al. (2017) who declared that, the number of the cases was increased significantly after the revolution of 2011 in Port Said. Also Sameh et al. (2016) agreed with our results in that the incidence increased sharply after the revolution and disagree with our results in that the highest percent of patients was in the year 2013 and the lowest percent was in the year 2009 as six cases. United Nations Office (2013) reported that the incidence of firearm homicides in Egypt increased from one homicide for every 100,000 people in 2010 to 3.5 per 100,000 people after the revolution of 25 th of January 2011.

The cause of the high percentage of firearm crimes in 2011 can be attributed to the inadequate performance of police authorities with shortage or absence of individual protection, in addition to high rate of unlicensed firearm possession among civilians. Moreover, many of the weapons in the police stations were stolen during the revolution and these weapons were used subsequently in murder and in political conflicts. 
In the current study, the least percentage of firearm injuries was recorded in 2016 (4.7\%). this can be explained by the stable political and security circumstances in 2016. This coincides with El Kamouni et al. (2018) who reported that analysis of conflict events in Libya showed the steady decrease of violent incidents and fatalities from 2015 to 2017.

It was noted that the rate of homicide per 100,000 people (total and by Firearm guns) in Tunisia does not show significant changes after Tunisian Revolution, this is against the results of current study. Multiple causes had led to this stability in the prevalence of all types of crimes. The most effective reason is that riots in Tunisia were rare and noteworthy. Another reason is the exceptionally strict firearm controls prompting low weapon murders rate, the manufacture of small arms, ammunition or potentially their parts is allowed just if the producer holds a valid license (Baker, 2011).

The increased incidence of firearm injuries in Fayoum governorate can be attributed to presence of many types of weapons with farmers and the geographic nature of this area with less police control and less stability of security. Low socioeconomic and educational levels in the studied area especially rural places is also an important cause of the increased prevalence of all types of crimes in Fayoum Governorate after the revolution of January 2011.

There are numerous risk factors for being a victim of firearm injury. They include young age and late puberty, male sex, low financial status, indigenous ethnicity, access to a gun in the home and association in a gang. Rural inhabitant was prescient of unexpected firearm injury and urban residence was emphatically connected with danger of assault from a gun (Leventhal et al., 2014).

In our study, $89 \%$ of study group were males versus $11 \%$ were females. This was in agreement with the findings of Hagras and Kharoshah (2012) where males constituted $96.6 \%$ and Nasrullah and Abdel Razzak (2009) where males constituted 92\% of the study population in Suez Canal area, Egypt and Karachi, Pakistan respectively. Studies carried out in India, Germany, and Nigeria to evaluate firearm injuries showed that, most victims were male in the age group of 20- 30 years. In the Transkei region of South Africa, a study to determine the prevalence of firearm fatalities found that, males represent $82 \%$ of the victims (Davies and Lecky, 2009; Meel, 2007).

This can be explained by males are unable to overcome their feelings of rage in their everyday activities since they generally go to work, where violence is ensured. Males are more influenced than females since they are required to keep up honour of the family and any risk to it that can prompt brutality, while females will in general stay inside. Likewise, females are more uncertain to take part in battles that could prompt homicide (Hagras and Kharoshah, 2012).

As regard the residence, firearm crimes in this study are more in rural sites $60 \%$ versus urban $40 \%$. This may be explained by low socioeconomic and educational levels as possession of weapons is common there with less monitoring of authorities. This was in agreement with Hagras and Kharoshah (2012) who reported firearm injuries were more common in rural areas (56\%) than urban places (44\%). Also in a study carried out in El-Fayoum Governorate, 52 cases (73.2\%) of firearm crimes occurred in rural areas while 19 cases $(26.8 \%)$ occurred in urban areas (Gamal Eldin et al., 2008) and a study carried out in Menoufiya University Hospital on firearm injuries which reported that firearm injuries were more common in rural areas than in urban areas (72.41\% and $27.59 \%$, respectively) (Maklad et al., 2004).

Our results reported that, no statistically significant difference was found between different years of the study and other variables. This may be explained by the similarity in culture and populations in Fayoum governorate which didn't change by years with same traditions and customs before and after the revolution. To our knowledge there weren't any studies regarding these correlations to compare with our results.

On the other hand, this study showed that shot guns were used more, especially in a quarrel and limbs were the most common site of injury. the easy availability of non -rifled guns and its cheap price compared to rifled guns.

This was opposite to what was found by Sameh et al. (2016)) who reported that, high-velocity weapons were the most commonly used in the prerevolution period representing $86 \%$ of cases and Hagras and Kharoshah (2012) who reported that automatic machine guns were commonly used. Also, a study of firearm fatalities in El-Fayoum Governorate during a 7-year period found that, 55 cases committed by using handmade firearms (Gamal Eldin et al., 2008), in contrast to study done in Alexandria found that the most common type of handgun used was either a revolver or a pistol (51.9\%), followed by home-made shotguns in 25.9\% (Abd El-Salam et al, 2006).

Locally made illicit guns are usually utilized in criminal cases in developing countries. One of the conceivable reasons for the advancement of privately made guns is that these weapons are exceptionally shoddy and are promptly accessible for criminals. Also, getting an authorized gun is troublesome (Saleh, 2010).

Regarding the cause of injury, the findings by Hagras and Kharoshah (2012) agree with our results as she reported that the most common cause was homicides. Also in a study in Menoufiya by Maklad et al. (2004) reported homicide in $71 \%$ and suicide in $29 \%$ of cases. Sameh et al (2016) who declared that, quarrel causes had decreased in the post-revolution period by about 3\%. Contrary to our results, Denmark and New Zealand studies showed that, suicides accounted for the vast majority of firearm fatalities (Adawiyah et al, 2018).

Regarding the site of wounds, and in contrast to our results, Saleh (2010) in a study of firearm injuries and death in Qena Governorate in Egypt reported that the most common site of wounds was the chest and the abdomen, representing 23.3\% and 22.3\%, respectively. Also, another study in El-Fayoum 
Governorate, the most common site was the chest followed by the abdomen (Gamal Eldin et al, 2008). Hagras and Kharoshah(2012) (2012) reported that that the common site of injury was chest.

This study showed a significantly statistical difference between type of weapon in relation to each of gender, residence and site of injury. Also there was no statistically significant difference in fatality rate as regards residence and the death rate was low compared to other studies.

These findings were to some extent logic in our opinion as in Fayoum governorate the community is tribal society especially in rural places where males are responsible for honour of the family, protecting their land and incorporated in daily life problems. Also guns are easy accessible by homemade or purchasing from each other outside the police supervision and Frequent disputes over the boundaries of agricultural land. When there is a dispute over any problem between tribes, each tribe tries to frighten the other and impose its control over it and show its strength with full care to ensure that there are no victims for fear of retaliation and thus causing injuries in the limbs, hence low fatality rate.

Also there was no statistically significant difference in fatality rate as regards residence and the death rate was low compared to other studies by Samy et al.( 2017), Hagras and Kharoshah(2012), Saleh(2010), Maklad et al.(2004) who reported a higher fatality rate.

\section{Conclusion and Recommendation}

The current study results highlighted the problem of firearm injuries in Fayoum governorate, also these results can help the government and the police authorities to find a solution for the spread of guns in Fayoum, for example, expanding supervision along country border where guns are regularly smuggled and illegally obtained. Law enforcement and security stability are very essential to minimize the spread of firearm violence, also, new restrictions to eliminate illegal firearm sales. There is a need for educational efforts, to increase awareness of youth against violence, improving the economic conditions and combating ignorance and illiteracy prevalent in Fayoum Governorate, especially in rural areas. This is what the Egyptian state is currently seeking and is focusing on its top priorities. Through our work we did not find enough published data to compare our results and we recommend further studies to be done for this period.

\section{References}

Abd El-Salam H, Darwish R, Madkour S et al., (2006): Retrospective and prospective study on the prevalence of fatal and non- fatal firearm injuries in Alexandria. Egypt J Forensic Sci Appl Toxicol. 6(2):107-27.

Adawiyah R, Hamzah NH, Hamzah AP et al., (2018): Incidence of firearm-related deaths and epidemology in Klang valley, Malaysia from 2006 to 2016: A retrospective study. Malaysian Journal of Public Health Medicine. (1): 51-61.
Baker DJ (2011). "Chapter 11". Glanville Williams Textbook of Criminal Law. London. pp.127130

Braga AA, Wintemute GJ, Pierce GL et al., (2012): Interpreting the empirical evidence on illegal gun market dynamics. Journal of Urban Health, 89(5): 779-793.

Davies M and Lecky F (2009): Analysis of injuries and deaths caused by firearms in England and Wales. J Injury. 40(10):185.

El Kamouni F, Shadeedi H and Ezzeddine N (2018): Local security governance in Libya. Clingendael.

Evoy MC and Hideg G (2017): GLOBAL VIOLENT DEATHS report. publication of the Small Arms Survey with support from the Swiss Agency for Development and Cooperation

Gamal Eldin A, El-Ghamry H, Ghaleb S et al., (2008): Study of cases of firearms fatalities in ElFayoum Governorate during 7 years period (2000-2006) retrospective study. Beni Sueif Univ Med J. 1(1):70-92.

Hagras AM and Kharoshah MA. (2012): MedicoLegal evaluation of firearm injuries during the period from 2005 to 2010 in Suez Canal Area, Egypt: A retrospective study. Egyption Journal of Forensic Sciences. 2:1-10.

Khetran AK, Rehman S, Khan Z et al., (2012): Incidence of Deaths due to Gunshot Injuries at District Barkhan, Balochistan. Original Article. 11: 02.

Leventhal JM, Gaither JR and Sege R. (2014): Hospitalizations due to firearm injuries in children and adolescents. Pediatrics 133:21925.

Lustenberger T, Inaba K, Schnüriger B, Barmparas G, Eberle BM, Lam L, et al. (2011): Gunshot injuries in the elderly. Patterns and outcomes. A national trauma data bank analysis. World J Surg. 35(3):528-34.

Maklad A, El-Mehy L and Mohdy M. (2004): A medico-legal study of firearm injuries in ElMonofia Governorate. Ain Shams J Forensic Med Clin Toxicol. 2:1-19

McGuire M, Manno M, Rook A, et al. (2011): Goods for Gunsethe use of a gun buyback as an injury prevention/community education tool. J Trauma.71: 537-540

Meel B (2007): Trends in firearm related deaths in the Transkei region of South Africa. Am J Forensic Med Pathol. 28:86-90.

Mohammed AZ, Edino ST, Ochicha O et al., (2005): Epidemiology of gunshot injuries in Kano, Nigeria. Nigerian Journal of Surgical Research. 7(3):296-9.

Naghavi M and Marczak LB (2018): Global Mortality From Firearms, 1990-2016. JAMA. 320(8):792-814.

Nasrullah M and Abdel Razzak J. (2009): Firearm Injuries Presenting to a Tertiary Care Hospital of Karachi, Pakistan. Journals of Injury and Violence Researches. 1(1):27-31. 
Sachan R, Kumar A and Verma A (2013): A Frequency of Firearm Injuries, Deaths and Related Factors in Kanpur, India; an Original Study with Review of Literature. International Journal of Medical Toxicology and Forensic Medicine. 3(3): 88-95.

Saidi HS, Nyakiamo J and Faya S (2002): Gunshot injuries as seen at the Aga Khan Hospital, Nairobi, Kenya. East Africa Medical Journal. 79:188-92.

Saleh SM (2010): A preliminary study of firearm injury and death in Qena Governorate, Egypt in year 2008. Ain Shams J Forensic Med Clin Toxicol. 10(5): 99-112.

Sameh S, Salama KM and Amr M (2016): Incidence, topography, types of firearm injuries before and after the revolution of the 25th of January 2011: a hospital-based study. International Surgery Journal. 3(3):1193-1198.
Samy A, Ahmed SA, Abdelfattah K et al., (2017): Forensic Analysis of Firearm Injuries in Port said Governorate during the 2011. Egyptian Revolution. J J Foren Sci. 3(1): 015.

Shenassa ED, Rogers ML, Spalding KL et al., (2004): Safer storage of firearms at home and risk of suicide: a study of protective factors in a nationally representative sample. Journal of Epidemiology and Community Health 58(10): 841-848.

United Nations Office on Drugs and Crime in global study on homicide book 2013, Percentage distribution of intentional homicides by mechanism and by country/territory (20002012): 140 .

WHO (2016): Inter-country Comparison of Mortality for Selected Causes of Death. WHO Mortality Data Base. Geneva: World Health Organization.

\section{الملخص العربيى}

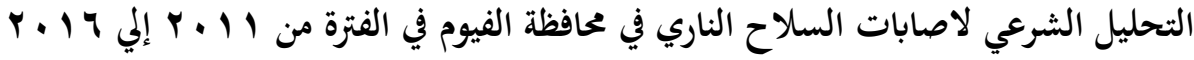

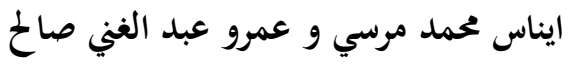

$$
\begin{aligned}
& \text { المقدمة: إصابة السلاح الناري هي سبب رئيسي للاعياء والوفيات. معدل الحدوث يختلف مع الوقت و بين المواقع المختلفه }
\end{aligned}
$$

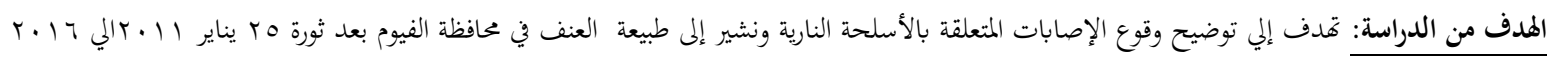

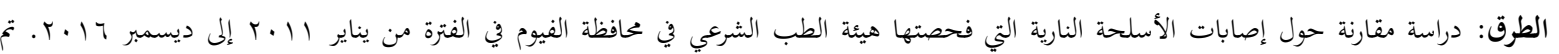

$$
\begin{aligned}
& \text { استبعاد إصابات الأسلحة النارية المتعلقة بالمظاهرات أو الأحداث السون السياسية. }
\end{aligned}
$$

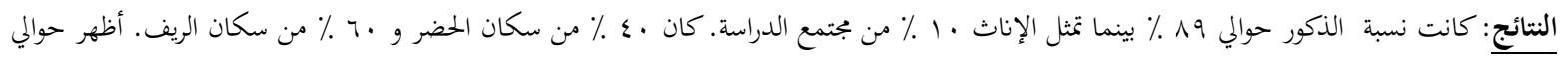

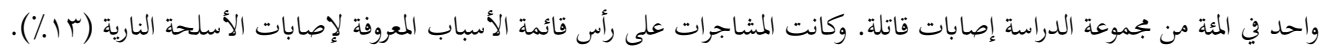

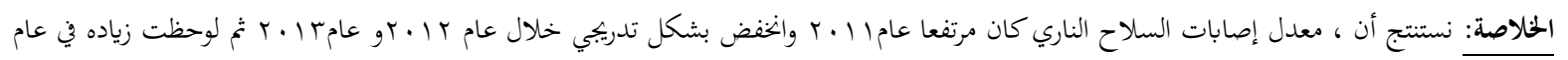

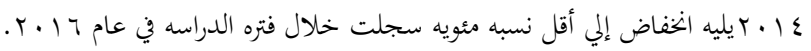

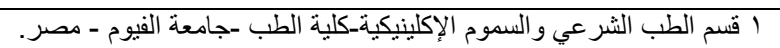

